\title{
Efficacy of Probiotics on Survival, Growth, Biochemical Changes and Energy Utilization Performance of Macrobrachium rosenbergii (De Man 1879) Post-larvae
}

\author{
C. Seenivasan*, S. Radhakrishnan, T. Muralisankar, and P. S. Bhavan \\ Crustacean Biology Laboratory, Department of Zoology, Bharathiar University, Coimbatore- \\ 641046, Tamilnadu, India
}

Received 26 March 2012, accepted in final revised form 18 August 2012

\begin{abstract}
The efficacy of combined probiotics, Lactobacillus sporogenes and Saccharomyces cerevisiae (LS+SC) on survival, growth, biochemical changes and energy utilization of Macrobrachium rosenbergii post larvae (PL) was examined. Each probiotic organism was individually tested at four different concentrations (1-4\%) separately. The best concentration in each probiotic species was combined and tested for its suitability in aquaculture usage. The basal diet was incorporated with probiotics, LS+SC (4:4) at five different concentrations $0 \%$ (control), $1 \%, 2 \%, 3 \%$ and $4 \%$. These diets were fed to $M$. rosenbergii PL for a period of 90 days. After the feeding trail, 2\% LS+SC incorporated diet had significantly $(P<0.05)$ higher survival, WG, SGR, FCE and PER compared with other experimental groups than the control. Whereas, the FCR was significantly $(P<0.05)$ lower in $2 \%$ LS+SC incorporated diet fed PL. Similarly the proximate composition of the protein, amino acid, carbohydrate, lipid and ash content were significantly $(P<0.05)$ higher in $2 \%$ LS+SC incorporated diet fed PL than the control. The energy utilization parameters were significantly $(P<0.05)$ higher in $2 \%$ LS+SC incorporated diet fed PL than the control. This study indicated that combined probiotics, LS+SC incorporated diets were beneficial for M. rosenbergii in terms of increasing growth and enhancing energy utilization performances.
\end{abstract}

Keywords: M. rosenbergii; Growth; Biochemical composition; Energy utilization; L. sporogenes; $S$. cerevisiae.

(c) 2012 JSR Publications. ISSN: 2070-0237 (Print); 2070-0245 (Online). All rights reserved.

doi: http://dx.doi.org/10.3329/jsr.v4i3.10193 J. Sci. Res. 4 (3), 729-740 (2012)

\section{Introduction}

The giant river prawn, Macrobrachium rosenbergii is one among crustaceans, native to Southeast Asia, South Pacific countries, northern Oceania, and Western Pacific islands. $M$. rosenbergii has become the main freshwater prawn species for small-scale and largescale farming because of its fast growth, large size, better meat quality, omnivorous feeding habit and established domestic and export markets in Asia [1]. A probiotic is

"Corresponding author: crustaceanseenu@gmail.com, crustaceanseenu@yahoo.com 
generally defined as a live microbial food supplement, which improves the balance of the host animals' intestinal flora [2]. The use of probiotics in the aquatic organisms is increasing with the demand for more environment-friendly aquaculture practices [3]. A number of studies have shown that probiotics can improve the survival, growth and biochemical changes of the freshwater prawn $M$. rosenbergii [4-13]. Therefore, the present study was undertaken to determine the effect of feeding combined probiotics, Lactobacillus sporogenes and yeast Saccharomyces cerevisiae on the survival, growth, biochemical changes and energy utilization performance of the freshwater prawn $M$. rosenbergii PL.

\section{Materials and Methods}

The post larvae of freshwater prawn, M. rosenbergii (PL 15) were purchased from a Happy Bay Annexe, Kanchipuram, Tamilnadu, India and were stocked in a cement tank $(1000$ L) filled with freshwater. The PL were acclimatised at ambient laboratory conditions for 15 days (up to PL 30) and starved for $24 \mathrm{~h}$ before the commencement of the feeding experiment. The experimental water had these physicochemical parameters: $\mathrm{pH}$, 7.20 \pm 0.30 ; total dissolved solids, $0.98 \pm 0.10 \mathrm{gL}^{-1}$; dissolved oxygen, $7.30 \pm 0.40 \mathrm{mg} / \mathrm{L}^{-1}$; BOD, $4.00 \pm 1.60 \mathrm{mg} / \mathrm{L}^{-1}$; COD, $10.00 \pm 9.00 \mathrm{mg} / \mathrm{L}^{-1}$ and ammonia, $0.068 \pm 0.008 \mathrm{mg} / \mathrm{L}^{-1}$.

Table 1. Ingredients and proximate composition of prepared diets.

\begin{tabular}{llllll}
\hline Ingredients (\%) & Control & \multicolumn{4}{c}{ Experimental diets } \\
& & \multicolumn{4}{c}{ ( L. sporogenes + S. cerevisiae incorporated) } \\
\cline { 3 - 6 } & & $1 \%$ & $2 \%$ & $3 \%$ & $4 \%$ \\
\hline Fish meal & 33.84 & 33.84 & 33.84 & 34.84 & 35.84 \\
Ground nut oil cake & 25.00 & 25.00 & 25.00 & 25.00 & 24.00 \\
Soybean meal & 24.00 & 24.00 & 23.00 & 21.00 & 20.00 \\
Corn flour & 4.00 & 3.00 & 3.00 & 3.00 & 3.00 \\
Egg albumin & 5.06 & 5.06 & 5.06 & 5.06 & 5.06 \\
Tapioca flour & 5.10 & 5.10 & 5.10 & 5.10 & 5.10 \\
Cod liver oil & 2.00 & 2.00 & 2.00 & 2.00 & 2.00 \\
Vitamin B-complex mix & 1.00 & 1.00 & 1.00 & 1.00 & 1.00 \\
Probiotics (LS+SC) & 0.00 & 1.00 & 2.00 & 3.00 & 4.00 \\
Proximate composition & & & & & \\
Protein (\%) & 40.10 & 40.00 & 39.63 & 39.52 & 39.40 \\
Carbohydrate (\%) & 21.76 & 21.10 & 20.71 & 20.01 & 19.50 \\
Lipid (\%) & 9.28 & 9.24 & 9.17 & 9.08 & 8.90 \\
Ash (\%) & 14.00 & 13.00 & 12.00 & 13.00 & 14.00 \\
Moisture (\%) & 9.50 & 9.90 & 9.40 & 9.10 & 9.10 \\
Digestible energy (k.cal/kg) & 3296.86 & 3262.52 & 3228.17 & 3193.83 & 3159.49 \\
\hline
\end{tabular}




\subsection{Diet preparation}

The composition of the experimental diets is given in Table 1. The probiotics, $L$. sporogenes (Uni-Sankyo Ltd, Maharashtra, India) and yeast S. cerevisiae (Intercare Ltd, Gujarat, India) one gram of lyophilized powders contains $15 \times 10^{7}$ and $10 \times 10^{7} \mathrm{cfu}$ cells respectively. The probiotics, LS+SC (4:4) were incorporated in to the test diets at five different concentrations individually $0 \%$ (control), $1 \%, 2 \%, 3 \%$ and $4 \%$ respectively. Diet formulation was done basically by "Pearson's square-method"' using determined values of $40 \%$ protein content (Table 1). The proportion of each ingredient required was calculated precisely providing allowance for the premix. The dough was steam cooked and cooled to room temperature. After that different concentration of LS+SC (4:4) was mixed with the dough and the diets were pelletized separately with a locally made (Kolkata, India) hand pelletizer. The pellets were dried in a thermostatic oven (M/s Modern Industrial, Mumbai, India) at $40^{\circ} \mathrm{C}$ until it reached constant weight and stored in airtight jars at room temperature.

\subsection{Feeding experiment}

M. rosenbergii (PL-30) with the length and weight range of $1.54 \pm 0.02 \mathrm{~cm}$ and $0.22 \pm 0.03 \mathrm{~g}$ respectively were used for feeding experiment. 40 PL for each diet in triplicate were maintained in plastic tanks with $20 \mathrm{~L}$ water. The PL was maintained at the stocking density of 2/l. One group served as control, which devoid of probiotics (0\%). The experimental groups were fed with the respective concentration of LS+SC (4:4) incorporated diets. The feeding was adjusted to two times a day (6:00 am and 6:00 pm). The daily ration was given at the rate of $10 \%$ of the body weight of PL with two equal half throughout the experimental period. The unfed feed, faeces and moult if any, were collected after the respective hours of feeding. The feeding experiment was prolonged for 90 days; mild aeration was given continuously in order to maintain the optimal oxygen level.

\subsection{Growth study}

After the feeding trial, the growth parameters such as survival (S), weight gain (WG), specific growth rate (SGR), feed conversion rate (FCR), feed conversion efficiency (FCE) and protein efficiency rate (PER) were individually determined by following equations [6].

Survival $(\%)=$ Total no. of live animals/Total no. of initial animals $\times 100$

Weight gain $(\mathrm{g})=$ Final weight $(\mathrm{g})-$ Initial weight $(\mathrm{g})$

SGR $(\%)=\log w_{2}-\log w_{1} / t \times 100$ (where, $w_{1}$ and $w_{2}=$ Initial and final weight, respectively (g), and $t=$ Total number of experimental days)

Feed conversion rate $(\mathrm{g})=$ Total feed intake $(\mathrm{g}) /$ Total weight gain of the prawn $(\mathrm{g})$

Feed conversion efficiency $(\%)=$ Biomass $(g) /$ Total Feed intake $(g) \times 100$

Protein efficiency rate $(\mathrm{g})=$ Total weight gain of PL (g)/Total protein consumed (g) 


\subsection{Energy utilization study}

The energy content of whole prawns, feeds, moult and faeces was measured using Parr 1281 Oxygen Bomb Calorimeter. The energy budget was calculated using the equation ( $C$ $\left.=\left(P_{g}+E\right)+R+F+U\right)$ derived by Petrusewicz and Macfadyen [14]; where, $C$ is the energy consumed in food; $P_{g}$ is the growth; $\mathrm{R}$ is the material lost as heat due to metabolism; $F$ is the energy lost in faeces; $U$ is the energy lost in excretion and; $E$ is the energy lost in exuvia.

Feeding rate $(\mathrm{FR})=$ Mean food consumption $(\mathrm{kcal} /$ day $) /$ Initial live wt. of the prawn (g)

Mean absorption = Mean food consumption (kcal/day) - Mean food excreted as faeces (kcal/day)

Absorption rate $(\mathrm{AR})=$ Mean absorption $(\mathrm{kcal} /$ day $) /$ Initial live wt. of the prawn (g)

Mean conversion $=$ Mean weight gain $(\mathrm{kcal} / \mathrm{day})+$ Mean exuvial weight $(\mathrm{kcal} / \mathrm{day})$

Conversion rate $(\mathrm{CR})=$ Mean conversion $(\mathrm{kcal} /$ day)/Initial live wt. of the prawn (g)

$\mathrm{NH}_{3}$ excretion rate $(\mathrm{AE})=$ Mean $\mathrm{NH}_{3}$ excretion (kcal/day) /Initial live wt. of the prawn (g)

Metabolic Rate $(\mathrm{MR})=$ Absorption rate $(\mathrm{kcal} / \mathrm{g} / \mathrm{day})$ - Conversion rate $(\mathrm{kcal} / \mathrm{g} / \mathrm{day})+$ $\mathrm{NH}_{3}$ excretion rate (kcal/g/day).

\subsection{Biochemical constituents of the experimental animals}

The initial and final day of the experiment, the biochemical constituents of the experimental animals were determined. The biochemical constituents, such as total protein [15], amino acid [16], lipid [17], carbohydrate [18], ash and moisture contents [19] of individual diet fed prawns were measured.

\subsection{Microbial study}

Microbial analyses [19], and yeast isolation [20] were performed in the rearing (control) water, control PL gut and experimental PL gut.

\subsection{Statistical analyses}

The data obtained in the present study were subjected to different statistical interpretations. One way analysis of variance (ANOVA; SPSS, 13.0) was used to determine whether significant variation between the treatments existed. Differences between means were determined and compared by post hoc multiple comparison test (DMRT). All the tests used a significance level of $P<0.05$. Data are reported as mean \pm standard deviations. 


\section{Results and Discussion}

\subsection{Morphometric data}

Table 2 represents the morphometric data of LS+SC (4:4) supplemented diet fed PL group. The initial average body length and weight of PL was $1.54 \pm 0.02 \mathrm{~cm}$ and $0.22 \pm 0.03 \mathrm{~g}$, respectively. After 90 days of feeding experiment, the final length and weight were found to be higher in PL fed with $2 \% \mathrm{LS}+\mathrm{SC}$ incorporated diet followed by the other experimental groups such as $3 \% \mathrm{LS}+\mathrm{SC}, 4 \% \mathrm{LS}+\mathrm{SC}$ and $1 \% \mathrm{LS}+\mathrm{SC}$ diets than the control. These differences were found to be statistically significant $(P<0.05)$. Similar

Table 2. The morphometric data, growth performance, biochemical constituents and energy utilization of $M$. rosenbergii PL fed with $L$. sporogenes $+S$. cerevisiae (4:4) incorporated diets.

\begin{tabular}{|c|c|c|c|c|c|c|}
\hline \multirow[t]{2}{*}{ Parameters } & \multirow[t]{2}{*}{ Control diet } & \multicolumn{4}{|c|}{ Experimental diets } & \multirow{2}{*}{$\begin{array}{l}\text { F- } \\
\text { Value }\end{array}$} \\
\hline & & $1 \% \mathrm{LS}+\mathrm{SC}$ & $2 \% \mathrm{LS}+\mathrm{SC}$ & $3 \% \mathrm{LS}+\mathrm{SC}$ & $4 \% \mathrm{LS}+\mathrm{SC}$ & \\
\hline Initial length (cm) & $1.54 \pm 0.02$ & $1.54 \pm 0.02$ & $1.54 \pm 0.02$ & $1.54 \pm 0.02$ & $1.54 \pm 0.02$ & - \\
\hline Final length (cm) & $4.70^{\mathrm{b}} \pm 0.24$ & $5.42^{\mathrm{a}} \pm 0.31$ & $5.94^{\mathrm{a}} \pm 0.26$ & $5.74^{\mathrm{a}} \pm 0.27$ & $5.50^{\mathrm{a}} \pm 0.30$ & 8.68 \\
\hline Initial weight (g) & $0.22 \pm 0.03$ & $0.22 \pm 0.03$ & $0.22 \pm 0.03$ & $0.22 \pm 0.03$ & $0.22 \pm 0.03$ & - \\
\hline Final weight (g) & $1.16^{\mathrm{b}} \pm 0.10$ & $1.60^{\mathrm{ab}} \pm 0.18$ & $1.93^{\mathrm{a}} \pm 0.22$ & $1.85^{\mathrm{a}} \pm 0.31$ & $1.68^{\mathrm{a}} \pm 0.40$ & 3.91 \\
\hline S (\%) & $80.00 \pm 2.50^{\mathrm{b}}$ & $85.00 \pm 2.50^{\mathrm{ab}}$ & $87.50 \pm 2.50^{\mathrm{a}}$ & $82.50 \pm 3.00^{\mathrm{ab}}$ & $80.00 \pm 3.00^{\mathrm{b}}$ & 4.34 \\
\hline WG (g) & $0.94 \pm 0.10^{c}$ & $1.38 \pm 0.14^{\mathrm{b}}$ & $1.71 \pm 0.16^{\mathrm{a}}$ & $1.63 \pm 0.20^{\mathrm{b}}$ & $1.46 \pm 0.19^{\mathrm{ab}}$ & 10.33 \\
\hline SGR (\%) & $0.802 \pm 0.026^{\mathrm{d}}$ & $0.957 \pm 0.034^{c}$ & $1.047 \pm 0.028^{\mathrm{a}}$ & $1.027 \pm 0.023^{\mathrm{ab}}$ & $0.980 \pm 0.034^{\mathrm{bc}}$ & 32.61 \\
\hline FCR (g) & $3.30 \pm 0.22^{\mathrm{a}}$ & $2.56 \pm 0.18^{\mathrm{b}}$ & $2.41 \pm 0.17^{\mathrm{b}}$ & $2.43 \pm 0.15^{\mathrm{b}}$ & $2.48 \pm 0.24^{\mathrm{b}}$ & 11.15 \\
\hline FCE (\%) & $0.94 \pm 0.09^{\mathrm{b}}$ & $1.34 \pm 0.15^{\mathrm{a}}$ & $1.46 \pm 0.22^{\mathrm{a}}$ & $1.53 \pm 0.13^{\mathrm{a}}$ & $1.39 \pm 0.24^{\mathrm{a}}$ & 5.20 \\
\hline PER (g) & $0.66 \pm 0.08^{\mathrm{b}}$ & $0.86 \pm 0.04^{\mathrm{a}}$ & $0.91 \pm 0.06^{\mathrm{a}}$ & $0.91 \pm 0.09^{\mathrm{a}}$ & $0.89 \pm 0.05^{\mathrm{a}}$ & 7.59 \\
\hline Protein (\%) & $59.40 \pm 3.70^{\mathrm{b}}$ & $61.80 \pm 2.60^{\mathrm{ab}}$ & $65.10 \pm 2.52^{\mathrm{a}}$ & $63.08 \pm 2.48^{\mathrm{ab}}$ & $62.08 \pm 2.68^{\mathrm{ab}}$ & 1.60 \\
\hline Amino acid (\%) & $23.14 \pm 2.48^{\mathrm{a}}$ & $26.08 \pm 2.69^{\mathrm{a}}$ & $28.60 \pm 3.74^{\mathrm{a}}$ & $27.00 \pm 3.00^{\mathrm{a}}$ & $24.90 \pm 2.96^{\mathrm{a}}$ & 1.42 \\
\hline Carbohydrate (\%) & $11.96 \pm 1.34^{\mathrm{c}}$ & $14.10 \pm 1.51^{\mathrm{bc}}$ & $18.00 \pm 1.28^{\mathrm{a}}$ & $16.20 \pm 1.92^{\mathrm{ab}}$ & $13.61 \pm 1.98^{\mathrm{bc}}$ & 6.24 \\
\hline Lipid (\%) & $9.00 \pm 1.73^{\mathrm{c}}$ & $12.00 \pm 1.44^{\mathrm{ab}}$ & $13.68 \pm 1.58^{\mathrm{a}}$ & $12.01 \pm 1.24^{\mathrm{ab}}$ & $10.60 \pm 1.52^{\mathrm{bc}}$ & 4.05 \\
\hline Ash (\%) & $16.00 \pm 1.37^{\mathrm{b}}$ & $18.00 \pm 1.09^{\mathrm{ab}}$ & $19.40 \pm 1.42^{\mathrm{b}}$ & $18.10 \pm 1.41^{\mathrm{ab}}$ & $17.10 \pm 1.26^{\mathrm{a}}$ & 2.77 \\
\hline Moisture (\%) & $76.42 \pm 4.05^{\mathrm{a}}$ & $76.00 \pm 3.38^{\mathrm{a}}$ & $75.00 \pm 3.43^{\mathrm{a}}$ & $75.30 \pm 3.19^{\mathrm{a}}$ & $76.30 \pm 3.00^{\mathrm{a}}$ & $<1$ \\
\hline FR (k.cal/g/day) & $0.396 \pm 0.028^{c}$ & $0.452 \pm 0.075^{d}$ & $0.520 \pm 0.082^{c}$ & $0.493 \pm 0.074^{c}$ & $0.459 \pm 0.058^{b}$ & 8.67 \\
\hline AR (k.cal/g/day) & $0.340 \pm 0.066^{\mathrm{b}}$ & $0.406 \pm 0.051^{c}$ & $0.489 \pm 0.049^{\mathrm{b}}$ & $0.452 \pm 0.010^{\mathrm{bc}}$ & $0.422 \pm 0.022^{\mathrm{ab}}$ & 20.29 \\
\hline CR (k.cal/g/day) & $0.212 \pm 0.092^{\mathrm{a}}$ & $0.253 \pm 0.067^{\mathrm{a}}$ & $0.325 \pm 0.052^{\mathrm{a}}$ & $0.293 \pm 0.047^{\mathrm{a}}$ & $0.274 \pm 0.060^{\mathrm{a}}$ & 12.06 \\
\hline AE (k.cal/g/day) & $0.011 \pm 0.007^{\mathrm{ab}}$ & $0.013 \pm 0.004^{\mathrm{ab}}$ & $0.021 \pm 0.006^{\mathrm{ab}}$ & $0.019 \pm 0.008^{\mathrm{a}}$ & $0.017 \pm 0.013^{\mathrm{ab}}$ & 6.14 \\
\hline MR (k.cal/g/day) & $0.139 \pm 0.022^{\mathrm{b}}$ & $0.166 \pm 0.031^{\mathrm{bc}}$ & $0.185 \pm 0.024^{\mathrm{b}}$ & $0.178 \pm 0.036^{\mathrm{ab}}$ & $0.165 \pm 0.029^{\mathrm{ab}}$ & 2.01 \\
\hline
\end{tabular}

Each value is a mean \pm SD of three replicate analysis, within each row means with different superscripts letters are statistically significant $\mathrm{P}<0.05$ (one way ANOVA and subsequently post hoc multiple comparison with DMRT).

S - survival; WG - weight gain; SGR - specific growth rate; FCR - feed conversion rate; FCE - feed conversion efficiency; PER protein efficiency rate; FR- feeding rate; AR- absorption rate; CR- conversion rate; $\mathrm{AE}$ - $\mathrm{NH}_{3}$ excretory rate; MR- metabolic rate 
improved morphometric data (length and weight) has been reported in $M$. rosenbergii PL fed with L. sporogenes bioencapsulated diets [5], Bacillus spp KKU02 and Bacillus spp KKU03 supplemented diets [11] and in shrimp, Penaus indicus after feeding with $L$. acidophilus, S. cremoris, L. bulgaricus-56 and L. bulgaricus-57 incorporated diets [21], Bacillus sp incorporated diets [22], Bacillus spp incorporated diets [23], B. subtilis UTM 126 incorporated diets [24].

\subsection{Survival performance}

Table 2 also depicted the survival performance of LS+SC (4:4) incorporated diet fed PL group. After 90 days of feeding trail, the survival performance of $M$. rosenbergii PL was found to be higher in $2 \%$ LS+SC incorporated diet. But it was only $80.00 \%$ in control diet fed prawn PL. On the other hand, the survival percentage of other experimental diets fed prawns was in the order of $1 \% \mathrm{LS}+\mathrm{SC}, 3 \% \mathrm{LS}+\mathrm{SC}, 4 \% \mathrm{LS}+\mathrm{SC}$. These differences were found to be statistically significant $(P<0.05)$. Similar improved survival has been reported in $M$. rosenbergii PL fed with $L$. sporogenes bioencapsulated diets [5], Binifit ${ }^{\mathrm{TM}}$ supplemented diets [6], Biogen ${ }^{\circledR}$ supplemented diets [8] and different probiotics supplemented diets [9], and in shrimps, fed with L. acidophilus, S. cremoris, L. bulgaricus-56 and L. bulgaricus-57 incorporated diets [21], B. subtilis incorporated diets [25] and Bacillus sp incorporated diets [26].

\subsection{Growth performance}

The results on growth performance of LS+SC (4:4) incorporated diet fed PL group are also displayed in Table 2. At the end of the feeding trail, the weight gain, specific growth rate, feed conversion efficiency and protein efficiency rate were significantly $(P<0.05)$ higher in probiotics LS+SC (4:4) incorporated diet fed groups than the control. The result on weight gain, specific growth rate, feed conversion efficiency and protein efficiency rate were found to be maximum in $2 \%$ LS+SC incorporated diet fed prawn PL, followed by $3 \%, 4 \%$ and $1 \%$ when compared with control. The differences between control and experimental diets fed prawns were statistically significant $(P<0.05)$. The feed conversion ratio was found to be higher in PL fed with control diet, followed by the PL fed with $1 \%$, $4 \%, 3 \%$ and $2 \%$ diets. These differences were found to be statistically significant $(P<0.05)$. Similar results have been reported in $M$. rosenbergii fed with $L$. sporogenes supplemented diets [4], bio-encapsulated L. sporogenes [5], Binifit ${ }^{\mathrm{TM}}$ incorporated diets [6], Bacillus spp supplemented diets [7], Biogen ${ }^{\circledR}$ incorporated diets [8], different probiotics supplemented diets [9], Bacillus spp KKU02 and Bacillus spp KKU03 incorporated diets [11], bio-encapsulated B. subtilis [10], Saccharomyces cerevisiae and yeast derivatives supplemented diets [27], bio-encapsulated L. acidophilus and $L$. sporogenes [12], bio-encapsulated L. ceremoris [13] and in fishes, L. plantarum and $B$. megaterium supplemented diets [28] Lactobacillus acidophilus and yeast Saccharomyces cervisiae incorporated diets [29], B. subtilis, B. licheniformis and Enterococcus faecium incorporated diets [30], bio-encapsulated L. casei [31], Bacillus spp supplemented diets 
[32], B. subtilis supplemented diets [33] and B. toyoi and B. cereus incorporated diets [34].

\subsection{Biochemical constituents of experimental animals}

The results on biochemical constituents, such as protein, amino acid, carbohydrate, lipid, ash and moisture content of LS+SC (4:4) incorporated diet fed PL group are also showed in Table 2. After the feeding trail experiment of 90 days, the protein, amino acid, carbohydrate, lipid and ash contents were found to be maximum in PL fed with $2 \%$ LS+SC diet, followed by the PL fed with $3 \%, 4 \%$ and $1 \%$ diets when compared with control. These differences were found to be statistically significant $(\mathrm{P}<0.05)$. In the case of moisture content just the reverse was recorded. A similar result in biochemical composition was previously observed in $M$. rosenbergii $\mathrm{PL}$ fed with $L$. sporogenes supplemented diet [4], bio-encapsulated L. sporogenes [5], Binifit ${ }^{\mathrm{TM}}$ supplemented diets [6], Biogen ${ }^{\circledR}$ incorporated diets [8] and bio-encapsulated $L$. sporogenes and $L$. acidophilus [12] and in fishes Lactobacillus acidophilus, and the yeast Saccharomyces cerevisiae supplemented diets [35], B. subtilis NIOFSD017 and L. plantarum NIOFSD018, and yeast S. cerevisiae NIOFSD019 incorporated diets [36], B. subtilis, B. licheniformis and Enterococcus faecium supplemented diets [30], Bacillus spp incorporated diets [32], Biogens ${ }^{\circledR}$ incorporated diets [37] and B. toyoi and B. cereus incorporated diets [34].

\subsection{Energy utilization performance}

The energy utilization performance of LS+SC (4:4) incorporated diet fed group of prawn $\mathrm{PL}$ is also paved in Table 2. The feeding rate, absorption rate, conversion rate, $\mathrm{NH}_{3}$ execratory rate and metabolic rate were found to be higher in PL fed with $2 \%$ LS+SC diet, followed by the PL fed with 3\%, $4 \%$ and $1 \%$ diets when compared with control. These differences were found to be statistically significant $(\mathrm{P}<0.05)$. Similarly, Seenivasan et al. [6] showed that Binifit ${ }^{\mathrm{TM}}$ supplemented diets had improved the energy utilization performance of freshwater prawn, M. rosenbergii PL. Dhanaraj et al. [29] noted that Lactobacillus acidophilus and yeast $S$. cerevisiae supplemented diets had improved the energy budget of Koi Carp, Cyprinus carpio. It has been reported in pearl spot, Etroplus suratensis fed with Lactobacillus and yeast supplemented diets had significantly improved the feed energy utilization performance [38]. It has also been reported in Nile tilapia of the nutrient energy utilization performance was higher in Saccharomyces cerevisiae supplemented diets [39]. EL-Haroun et al. [37] showed that Biogen ${ }^{\circledR}$ incorporated diets have improved the growth and feed energy utilization performance of Nile tilapia, Oreochromis niloticus. 


\subsection{Microbial study}

The qualitative microbial study showed presence of the rearing control medium and control PL gut following bacteria, such as Bacillus sp., Pseudomonas sp., E. coli, Streptococcus sp., and Klebsiella pneumonia in the Table 3 and 4. In the experimental PL, the presences of Klebsiella pneumonia were replaced by establishment of $L$. sporogenes

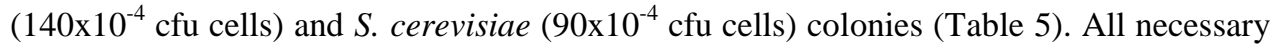
confirmation biochemical tests were performed and the results are presented (Tables 3 to $6)$.

Table 3. Biochemical characterization of isolates in control water.

\begin{tabular}{|c|c|c|c|c|c|c|}
\hline 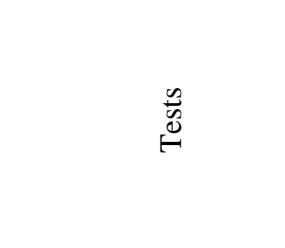 & 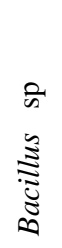 & 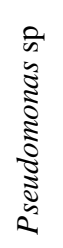 & $\begin{array}{l}: \overline{0} \\
0\end{array}$ & 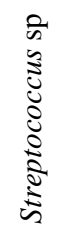 & 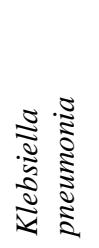 & 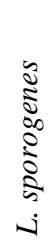 \\
\hline Gram's Staining & + & - & - & + & - & - \\
\hline Motility test & + & + & + & + & - & - \\
\hline Indole test & - & - & + & - & - & - \\
\hline Methyl red test & - & - & + & - & - & - \\
\hline VP test & - & + & - & + & + & - \\
\hline Citrate utilization test & + & + & - & + & + & - \\
\hline Starch hydrolases & + & - & + & + & + & - \\
\hline Gelatin hydrolases & + & + & + & + & + & - \\
\hline Nitrate reduction test & + & - & + & + & + & - \\
\hline Oxidase test & - & + & + & - & + & - \\
\hline Catalase test & + & + & - & - & + & - \\
\hline Glucose test & A & A & A & A & A & - \\
\hline Lactose test & A & NA & A & A & A & - \\
\hline Sucrose test & A & A & A & A & A & - \\
\hline Manitol test & A & A & A & A & A & - \\
\hline
\end{tabular}

+ = Positive; - =Negative; $\mathrm{A}=$ Acid production; NA = No acid production .

Similar results have been reported in the gut of $M$. rosenbergii PL fed with bioencapsulated $L$. sporogenes [5]. It has been reported in prawn, M. rosenbergii fed with bio-encapsulated $L$. sporogenes and $L$. acidophilus that established in the gut [12]. It has also been reported that the probiotic bacterial colonies established in the intestine of the 
shrimp, P. monodon fed with Bacillus S11 supplemented diets [40]. Colony establishment in the gut has also been reported in fishes, B. subtilis, L. lactis and S. cerevisiae in Labeo rohita [41], B. subtilis in the Indian major carps [42], L. acidophilus in Poecilia recticulata [43], Bacillus spp in Onchorhynchus mykiss [32], Lactobacillus spp in the sea bream, Sparus aurata [44], Lactobacil, sporolac, and yeast in Juvenile Goldfish, Carassius auratus [45] and Lactobacillus acidophilus and Saccharomyces cerevisiae in Etroplus suratensis [38].

Table 4. Biochemical characterization of isolates in control PL gut.

\begin{tabular}{|c|c|c|c|c|c|c|}
\hline$\stackrel{n}{\stackrel{n}{0}}$ & $\begin{array}{l}\text { के } \\
\stackrel{5}{\Xi} \\
\tilde{\Xi} \\
\tilde{D}\end{array}$ & 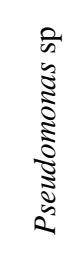 & $\begin{array}{c}\tilde{8} \\
0 \\
\text { 퍼 }\end{array}$ & 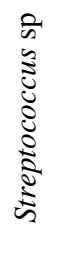 & 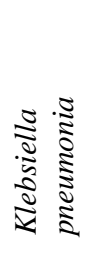 & 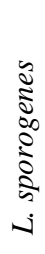 \\
\hline Gram’s sstaining & + & - & - & + & - & - \\
\hline Motility test & + & + & + & + & - & - \\
\hline Indole test & - & - & + & - & - & - \\
\hline Methyl red test & - & - & + & - & - & - \\
\hline VP test & - & + & - & + & + & - \\
\hline Citrate utilization test & + & + & - & + & + & - \\
\hline Starch hydrolases & + & - & + & + & + & - \\
\hline Gelatin hydrolases & + & + & + & + & + & - \\
\hline Nitrate reduction test & + & - & + & + & + & - \\
\hline Oxidase test & - & + & + & - & + & - \\
\hline Catalase test & + & + & - & - & + & - \\
\hline Glucose test & A & A & A & A & A & - \\
\hline Lactose test & A & NA & A & A & A & - \\
\hline Sucrose test & A & A & A & A & A & - \\
\hline Manitol test & A & A & A & A & A & - \\
\hline
\end{tabular}

+ = Positive; - = Negative; $\mathrm{A}$ = Acid production; NA = No acid production.

The present study concluded that the selected probiotics, LS+SC (4:4) from at optimized concentrations was found to enhance the survival, growth, tissue biochemical constituents and energy utilization of reared prawn M. rosenbergii. Further research on the diets produced with optimized concentration of the chosen probiotics organisms may be evaluated under field condition in the candidate species $M$. rosenbergii. 
Table 5. Biochemical characterization of isolates in experimental PL gut.

\begin{tabular}{|c|c|c|c|c|c|c|}
\hline$\stackrel{n}{\stackrel{n}{\oplus}}$ & 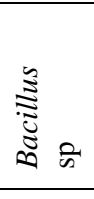 & 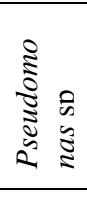 & $\begin{array}{l}\overline{8} \\
\overline{8}\end{array}$ & 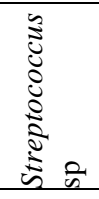 & 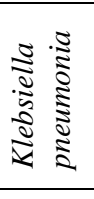 & 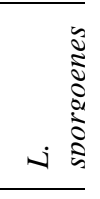 \\
\hline Gram's Staining & + & - & - & + & - & + \\
\hline Motility test & + & + & + & + & - & + \\
\hline Indole Test & - & - & + & - & - & - \\
\hline Methyl red Test & - & - & + & - & - & + \\
\hline VP Test & - & + & - & + & - & + \\
\hline Citrate Utilization Test & + & + & - & + & - & + \\
\hline Starch hydrolases & + & - & + & + & - & + \\
\hline Gelatin Hydrolases & + & + & + & + & - & + \\
\hline Nitrate reduction Test & + & - & + & + & - & - \\
\hline Oxidase Test & - & + & + & - & - & - \\
\hline Catalase Test & + & + & - & - & - & - \\
\hline Glucose Test & A & A & A & A & - & A \\
\hline Lactose Test & A & NA & A & A & - & A \\
\hline Sucrose Test & A & A & A & A & - & A \\
\hline Manitol Test & A & A & A & A & - & A \\
\hline
\end{tabular}

+ = Positive; - = Negative; $\mathrm{A}$ = Acid production; $\mathrm{NA}=$ No acid production .

Table 6. Overall result of microbial load in control water, control PL and experimental PL.

\begin{tabular}{llll}
\hline Isolate Name & $\begin{array}{l}\text { Control water } \\
\left(10^{-5}\right)\end{array}$ & Control PL gut & $\begin{array}{c}\text { Experimental PL gut } \\
(2 \% \mathrm{LS}+\mathrm{SC})\end{array}$ \\
\hline Bacillus sp & $\mathrm{P}$ & $\mathrm{P}$ & $\mathrm{P}$ \\
Pseudomonas sp & $\mathrm{P}$ & $\mathrm{P}$ & $\mathrm{P}$ \\
E. coli & $\mathrm{P}$ & $\mathrm{P}$ & $\mathrm{P}$ \\
Streptococcus sp & $\mathrm{P}$ & $\mathrm{P}$ & $\mathrm{P}$ \\
Klebsiella pneumoniae & $\mathrm{P}$ & $\mathrm{P}$ & $\mathrm{P}$ \\
L. sporogenes & $\mathrm{A}$ & $\mathrm{A}$ & $\mathrm{P}\left(140 \times 10^{-4} \mathrm{cfu}\right.$ cells $)$ \\
S. cerevisiae & $\mathrm{A}$ & $\mathrm{A}$ & $\mathrm{P}\left(90 \times 10^{-4} \mathrm{cfu}\right.$ cells $)$ \\
\hline
\end{tabular}

$\mathrm{P}=$ present; $\mathrm{A}=$ absent. 


\section{Acknowledgement}

The Bharathiar University, Coimbatore, Tamilnadu, India is gratefully acknowledged for the financial support provided in the form of University Research Fellowship to Mr. C. Seenivasan.

\section{References}

1. M. B. New, Aquacul. Res. 26, 54 (1995). http://dx.doi.org/10.1111/j.1365-2109.1995.tb00859.x

2. R. Fuller, J. Appl. Bacteriology 66, 365(1989). http://dx.doi.org/10.1111/j.1365-2672.1989.tb05105.x

3. F. J. Gatesoupe. Aquaculture 180, 147 (1999). http://dx.doi.org/10.1016/S0044-8486(99)00187-8

4. L. Prasad, B. B. Nayak, M. P. S. Kohli, A. K. Reddy, and P. P. Srivastava, Israeli J. Aquaculture 64, 676 (2012).

5. C. Seenivasan, P. S. Bhavan, S. Radhakrishnan, and R. Shanthi, Turki. J . Fis. Sci. 12, 23 (2012).

6. C. Seenivasan, P. Saravana Bhavan, and S. Radhakrishnan, Elixir Aquaculture 41, 5919 (2011).

7. K. Rinisha, M. K. M. Rahiman, R. M. Beevi, A. P. Thomas, and A. A. M. Hatha, Fishery Technology 47,173 (2010).

8. S. A. Saad, M. M. Habashy, and M. K. Sharshar, World Appl. Sci. J. 6, 550 (2009).

9. A. N. Shinde, V. B. Mulye, N. D. Chogale, V. R. Bhatkar, R. D. Bondre, and A. S. Mohite, Aquaculture 9, 7 (2008).

10. M. A. Keysami, C. R. Saad, K. Sijam, H. M. Daud, and A. R. Alimon, Aqua. Nutr. 13, 131 (2007). http://dx.doi.org/10.1111/j.1365-2095.2007.00463.x

11. S. Deeseenthum, V. Leelavatcharams, and D. J. Brook, Pak. J. Biol. Sci. 10, 1481 (2007). http://dx.doi.org/10.3923/pjbs.2007.1481.1485

12. H. K. Venkat, P. S. Narottam and K. J. Kamal., Aqua. Res. 35, 501 (2004). http://dx.doi.org/10.1111/j.1365-2109.2004.01045.x

13. V. Suralikar and N. P. Sahu, J. Appl. Anim. Res. 20, 117 (2001). http://dx.doi.org/10.1080/09712119.2001.9706744

14. K. Petrusewicz and A. Macfadyen. Productivity of Terrestrial Animals: Principles and Methods, IBP Handbook No. 13 (Blackwell, Oxford, 1970).

15. O. H. Lowry, W. J. Rosenbrough, A. L. Fair, and R. J. Randall. J. Biol. Chem. 193, 265 (1951). PMid:14907713

16. W. Moore and H. Stein. In: Methods in enzymol (eds: S. P. Olowick and N.D. Kaplan) (Academic press, New York, 1948) p. 468.

17. J. Folch, M. Lees, and G. H. Bloane-Stanley, J. Biol. Chem. 266, 497 (1957).

18. J. H. Roe, J. Biol. Chem. 212, 335 (1955). PMid:13233235

19. APHA. Standard Methods for the Examination of Water and Wastewater, $19^{\text {th }}$ edn. American Public Health Association, New York (2005).

20. P. I. Bowman and D. G. Ahearn, J. Clin. Microbiol. 2, 354 (1975). PMid:1102563 PMCid:362809

21. R. Fernandez, M. Sridhar and N. Sridhar, Res. J. Microbiol. 6, 466 (2011).

22. R. Gomez, D. Geovanny, and M. A. Shen. J. Ocean University of China 7, 215 (2008). http://dx.doi.org/10.1007/s11802-008-0215-x

23. T. Boonthai, V. Vuthhiphandchai, and S. Nimrat, Aquacult. Nutr. 17, 634 (2011). http://dx.doi.org/10.1111/j.1365-2095.2011.00865.x

24. J. L. Balcazar, I. De Blas, I. Ruiz-Zarzuela, D. Vendrell, A. C. Calvo, I. Márquez, O. Gironés, and G. L. Muzquiz. Br. J. Nutr. 97, 522 (2007). http://dx.doi.org/10.1017/S0007114507432986

25. W. Y. Shen, L. L. Fu, W. F. Li, and Y. R Zhu. Aqua. Res. 41, 1691 (2010). http://dx.doi.org/10.1111/j.1365-2109.2010.02554.x

26. S. Ziaei-Nejad, M. H. Rezaei, G. A. Takami, D. L. Lovett, A. R. Mirvaghefi, and M. Shakouri. 
Aquaculture. 252, 516 (2006). http://dx.doi.org/10.1016/j.aquaculture.2005.07.021

27. H. Hisano, R. D. Falcon, M. Maria Barrose, and E. L. Pezzato, Ciencia Animal Brasileira 9, 657 (2008)

28. R. Parthasarathy and D. Ravi, Indian J. Fish. 58, 87 (2011)

29. M. Dhanaraja, M. A. Haniffaa, S. V. Arun Singha, A. Jesu Arockiarajb, C. Muthu Ramakrishanana, S. Seetharamana, and R. Arthimanjua, J. Appl. Aquacult. 22, 202 (2010). http://dx.doi.org/10.1080/10454438.2010.497739

30. D. L. Merrifield, G. Bradley, R. T. M. Baker and S. J. Davies, Aquacult. Nutr. 16, 496 (2010). http://dx.doi.org/10.1111/j.1365-2095.2009.00688.x

31. H. H. L. Hernandez, J. C. Barrera Mejia, G. C. Mejia, M. Del Carmen, M. Dosta, R. De Lara Andrade, and J. A. M. Sotres, Aquacult Nutri. 16, 407 (2010). http://dx.doi.org/10.1111/j.1365-2095.2009.00679.x

32. T. Bagheri, S. Hedayati, V. Yavari, M. Alizade, and A. Farzanfar, Turk. J. Fish. Aqua. Sci. 8, 43 (2008).

33. S. Ghosh, A. Sinha, and C. Sahu, Aqua. Nutri. 14, 289 (2008). http://dx.doi.org/10.1111/j.1365-2095.2007.00529.x

34. M. C. Hidalgo, A. Skalli, N. E. Abella, M. Arizcun, and G. Cardenete, Aqua. Nutr. 12, 256 (2006). http://dx.doi.org/10.1111/j.1365-2095.2006.00408.x

35. M. Lara-Flores, L. Olivera-Castillo, and M. A. Olvera-Novoa, Int. J. Fisheries Aqua. 2, 93 (2010).

36. M. A. Essa, S. S. EL-Serafy, M. M. El-Ezabi, S. M. Daboor, N. A. Esmael, and S. P. Lall, J. Arabian Aqua. Soc. 5, 2 (2010).

37. E. R. EL-Haroun, A. M. A. S. Goda, and M. A. K. Chowdhury, Aqua. Res. 37, 1473 (2006).

38. G. Immanuel, V. Menethira, S. Beena and A. Palavesam, Indian J. Fish. 50, 273 (2003).

39. M. Abdel-Tawwab, A. M. Abdel-Rahman, and N. E. M. Ismael, Aquaculture 280, 185 (2008). http://dx.doi.org/10.1016/j.aquaculture.2008.03.055

40. S. Rengpipat, S. Runkpratanporn, S. Piyatiratitivorakul, and P. Menasaveta, Aquaculture 191, 271 (2000). http://dx.doi.org/10.1016/S0044-8486(00)00440-3

41. S. Mohapatra, T. Chakraborty, A. K. Prusty, P. Das, A. K. Paniprasad, and K. N. Mohanta, Aqua. Nutr. 18, 1 (2012). http://dx.doi.org/10.1111/j.1365-2095.2011.00866.x

42. S. K. Nayak and S. C. Mukherjee, Aqua. Res. 42, 1034 (2011). http://dx.doi.org/10.1111/j.1365-2109.2010.02686.x

43. P. R. Sreedevi and V. Ramasubramanian, Aqua. Int. 19, 789 (2011).

44. C. Suzer, D. Coban, O. H. Kamaci, S. Saka, K. Firat, O. Otgucuoglu, and H. Kucuksari. Aquaculture 280, 140 (2008). http://dx.doi.org/10.1016/j.aquaculture.2008.04.020

45. B. Ahilan, G. Shine, and R. Santhanam, Asian Fisheries Sci. 17, 271 (2004). 